\title{
Robo-AdVice in insurance distribution under Polish laW. OUTLINE OF THE PROBLEM ${ }^{1}$
}

\section{Introduction}

The article aims to present the issues of robo-advice in insurance distribution in Polish law after the implementation of the IDD directive. Due to the limited scope of this article, only some of the issues related to this issue will be discussed. The author focused her considerations on the essence, application of robo-advice in business insurance, as well as its admissibility in the Polish model of insurance distribution. It argues that in Polish law, advice to clients can only be provided by insurance brokers. The article indicates the types of cooperation between robo-advisers and a traditional insurance distributor and the imperfections of legal regulations in an outsourcing agreement. The applicable norms of civil law in the Polish law in the field of civil liability with regard to damages caused by artificial intelligence also do not keep up with the development of new technologies and require changes primarily at the level of EU law. In this regard, the responsibility for artificial activities intelligence requires specific statutory regulation, and that regulation liability for a dangerous product is insufficient in this range.

* Dr. habil., Associate Professor, Cracow Univeristy of Economics; e-mail: monika .szaraniec@uek.krakow.pl, https:/ / orcid.org/0000-0002-3721-3179.

1 Article written as a part of an individual grant received from the REV 4.0 project, entitled. Activities of insurance technology companies (InsurTech) and regulatory gaps distorting competition in the economic insurance market (G-REV-28-1-2019). 


\section{On the admissibility to provide advice under the Insurance Distribution Act}

October 2018 saw the entry into force of the Act of 15 December 2017 on insurance distribution, ${ }^{2}$ which is an effect of the implementation of the Directive (EU) 2016/97 of the European Parliament and of the Council of 20 January 2016 on insurance distribution (IDD) ${ }^{3}$ into the Polish legal system. The Directive is minimal, and that fact is of the essence to the adopted legal regime in Polish law, reflecting the provision of insurance advice by an insurance distributor.

Advice in the financial market should be considered in the context of disclosure requirements. It is indicated in literature that the obligation to provide advice, which takes the form of counselling, is complied with when the information provided offers the customer the reasons to make an appropriate decision and allows them to choose the form of financial service which is most favourable to their needs. ${ }^{4}$ Other authors also approach advice (counselling) as informative behaviour relevant to financial services. According to that view, advice is individualized and nonstandard. This means that the counselling party expresses advice and assesses specific circumstances and provides suggestions regarding the addressee's specific behaviour of such advice. Moreover, the party providing advice should determine the needs and purposes such advice is to serve. ${ }^{5}$

The provisions of the IDD impose on insurance distributors ${ }^{6}$ many new disclosure obligations vis-a-vis the customer ${ }^{7}$ and with regard to the provision of advice. ${ }^{8}$ It follows from Recital 45 of the IDD that

2 I.e. Journal of Laws of 2019 item 1881 (hereinafter referred to as IDA).

3 OJ L 26/19 of 2 February 2016 (hereinafter referred to as IDD).

4 So: B. Lewaszkiewicz-Petrykowska, Uwagi o zawodowym obowiazku udzielenia informacji, in: Z zagadnień wspótczesnego prawa cywilnego. Księga pamiątkowa ku czci Profesora Tomasza Dybowskiego, Warszawa 1994, p. 47.

5 So: P. Tereszkiewicz, Obowiazki informacyjne w umowach o ustugi finansowe, Warszawa 2015 , p. $48-52$.

6 Insurance distributors are: insurance undertakings, insurance agents, agents offering supplementary insurance as well as insurance or reinsurance brokers.

7 The IDD imposed on all distributors a precontractual obligation to perform an analysis of customer needs and to provide the customer, in a comprehensible form, with objective information on the insurance product to enable the customer's informed decision. So: Art. 20(1) IDD. In the IDA, this requirement was provided for in Art. 8 and relates to all distributors. 
[w]here advice is provided prior to the sale of an insurance product, in addition to the duty to specify the customers' demands and needs, a personalized recommendation should be provided to the customer explaining why a particular product best meets the customer's insurance demands and needs. Additionally, the EU legislator defines advice as provision of a personal recommendation to a customer, either upon their request or at the insurance distributor's initiative, in respect of one or more insurance contracts. ${ }^{9}$

The legislator also adds the activity of providing advice to distribution activities. ${ }^{10}$ Certain authors inferred from that legal solution that both the UE and Polish legislator resolved that each insurance distributor may advise customers. ${ }^{11}$

However, it must be noted that the provision of Art. 20(3) IDD introduces a solution under which

$[w]$ here an insurance intermediary informs the customer that it gives its advice on the basis of a fair and personal analysis, it shall give that advice on the basis of an analysis of a sufficiently large number of insurance contracts available on the market to enable it to make a personal recommendation, in accordance with professional criteria, regarding which insurance contract would be adequate to meet the customer's needs.

Apart from that provision, the EU legislator imposes, in Art. 18(1) (ii) IDD, a pre-contractual obligation on insurance distributors vis-a-vis customers requiring them to provide information if they offer advice relating to the sold insurance products. This means that the EU legislator allows for regulatory leeway concerning the provision of advice by insurance distributors and, in the same way, leaves discretion to national legislators in respect of defining the distribution model. ${ }^{12}$ By doing so, the EU legislator

8 Art. 20(3) IDD.

9 Art. 2(1) item 15 IDD.

10 See: Art. 2(1) item 1 IDD; the Polish legislator copied that definition in Art. 4 IDA.

11 D. Maśniak, K. Malinowska, Czynności dystrybucyjne w nowym reżimie zawierania umów ubezpieczenia - wybrane aspekty implementacji dyrektywy nr 2016/97 w sprawie dystrybucji ubezpieczeń, Prawo Asekuracyjne 2007, vol. 2, p. 28 et seq. Similar opinion was expressed in: D. Maśniak, Komentarz do art. 4 u.d.u., in: M. Fras, B. Kucharski, K. Malinowska, D. Maśniak, M. Szaraniec, Dystrybucja ubezpieczeń. Komentarz, Warszawa 2020, p. 83.

12 Consequently, the EU legislator distinguishes between intermediaries (distributors) providing advice services and intermediaries that do not render such services. However, all distributors will now be obliged to examine the customer's requirements and needs 
permits such distribution models where advice is provided to customers by all distributors and such models where only certain distributors provide advice. However, it is essential that the customer be notified of that fact and that providing advice should conclude with the customer being presented with individualized recommendation (which follows from the definition of advice as included in the IDD).

As I have already mentioned, the Polish legislator practically copied the definition of distribution activities from the IDD, among which the legislator listed the activity of the provision of advice by distributors. ${ }^{13}$ However, one should not jump to the conclusion that each insurance distributor may advise. This is shown by the fact that the legislator, at the beginning of the Insurance Distribution Act, pointed to the obligations to customers which are common to all distributors ${ }^{14}$ (e.g., performing analysis of customer needs prior to concluding the contract, provision of information about the product prior to concluding the contract, obligations to customers in cross-selling), whereas in Art. 22 IDA, ${ }^{15}$ Art. 23 IDA $^{16}$ and Art. 32 IDA $^{17}$ the legislator provided specific obligations specific to each distributor type, deciding not only about the distribution model (including insurance intermediation) in Poland, but also clearly resolving that only insurance or reinsurance brokers may advise the customer. It follows from Art. 32(1) item 4 that prior to concluding an insurance contract, a broker

shall provide advice based on reliable analysis of insurance products available in the market in the number sufficient to prepare a recommendation of the most appropriate contract, and shall explain the reasons on which the recommendation is based, considering the complexity of the insurance contract

based on the information received from such customer, and they will also be obliged to provide the customer, in a comprehensive form, with objective information about the insurance product so as to enable the customer's informed decision. On the other hand, distributors providing advice will be additionally obliged to offer reliable and individualized recommendation prepared on the basis of a sufficient number of insurance contracts available in the market.

13 See: Art. 4 IDA.

14 Art. 8-11 IDA.

15 This Article provides for precontractual obligations of insurance agents and agents offering supplementary insurance to customers.

16 This Article provides for precontractual obligations of an employee of the insurance undertaking vis-a-vis customers.

17 This Article provides for precontractual obligations of an insurance or reinsurance broker to the customer. 
or insurance guarantee contract and type of the customer, unless the customer submits a written statement of resignation from being advised.

Such construction of the Act and such specification of distributor obligations to customers dictate that advice may be provided to customers only by brokers under the Polish Insurance Distribution Act.

Insurance agents, agents offering supplementary insurance and employees of insurance undertakings (as distributors) do not provide advice and their obligation to customers is limited to providing guidance and drawing customers' attention to the specificity of a product when presenting the offer, having identified the customer's needs and having presented to the customer the information on the insurance product. Their activities in this regard should provide information about the actual situation and be of help in the search for the appropriate insurance contract. As a result, those distributors should be obliged to prepare an offer tailored to the policyholder's needs and expectations. It seems that such an obligation should be complied with both prior to the contract's conclusion and for its duration (such is the case in German law). ${ }^{18}$

The above considerations were necessary to resolve that robo-advice in insurance distribution under the Polish law will relate exclusively to the activities of insurance brokers (as customer's advisors), whereas in the case of remaining distributors, we will have to do with robo-offers (of the seller). Those considerations also allowed us to establish that the Polish legislator did not implement a fundamental (and essential from the point of view of advice) obligation to customers under Art. 18(1) (ii) IDD, consisting in the provision to the customer by every insurance distributor of the information if the distributor offers advice in relation to the sold insurance products. De lege ferenda, such obligation should be added to Art. 32(1) next to the broker's pre-contractual obligations o customers.

\section{The essence of robo-advice and its application to economic insurance}

The term robo-advisor refers to a specific group of entrepreneurs, operating in the form of Internet platforms, offering independent or

18 M. Fras, Umowa ubezpieczenia grupowego. Aspekty prawne, Warszawa 2015, p. 202 et seq. 
web-based software for managing investment portfolios (but also insurance $^{19}$ and banking portfolios) with the least possible involvement of human advisors. We will have to do with robo-advice on the financial market everywhere where customers contact advisors, e.g. we will have to do with a credit intermediary in the banking market, a broker in the insurance market, an investment advisor in the investment market. Automatic counselling is a part of artificial intelligence $(A l .)^{20}$ and may simplify or

19 As a matter of example of application of artificial intelligence and robo-advice in the broker's activities all over the world, one should point to Knip and Wefox (Switzerland), Clark and GetSafe (Germany), Worry + Peace and Simply Business (UK), Coverwallet and Embroker (USA).

20 It is difficult to define artificial intelligence. The European Parliament resolution of 16 February 2017 with recommendations to the Commission on Civil Law Rules on Robotics (OJ C 252 of 18.07.2018, p. 239) called on the European Commission to propose a common EU definition of cyber-physical systems, autonomous systems and their subcategories, taking into account the following features of intelligent machines: 1) acquisition of autonomy by sensors or exchange of data with the environment (mutual connections) as well as exchange and analysis of such data, 2) ability of self-learning based on the gained experience and interaction with the environment (facultative criterion), 3) at least minimum physical form, 4) adaptation of the machine's own behaviour and actions to the environment, 5) lack of vital functions in the biological sense. Following the Parliament, the European Commission, in the Communication of 25.04.2018 from the Commission to the European Parliament, the European Council, the Council, the European Economic and Social Committee and the Committee of the Regions "Artificial Intelligence for Europe" (COM/2018/237), defined artificial intelligence as systems that display intelligent behaviour by analysing their environment and taking actions - with some degree of autonomy - to achieve specific goals. In addition, in the glossary “Ethics Guidelines for Trustworthy Artificial Intelligence" of the High Level Expert Group for Artificial Intelligence appointed by the EC in June 2018, an explanation was made that: artificial intelligence systems are human-made computer software (and possibly also computer hardware) which, taking into account their comprehensive purpose, operate in the physical or digital dimension by perceiving their environment due to collecting data, interpreting the collected structured or non-structured data, reasoning on the basis of knowledge or processing information derived from such data and decision-making in respect of the best actions to be taken so as to achieve a specific purpose. Al systems may use symbolic rules or learn a numerical model, as well as adjust their behaviour by analysing the impact of their prior actions on the environment (Ethics Guidelines for the Trustworthy Artificial Intelligence, Brussels 2019, p. 48). Based on the foregoing, it seems legitimate to conclude that $\mathrm{Al}$ means computer systems including software which, due to environment analysis and taking actions to achieve specific purposes, display intelligent behaviour. So: A. Auleytner, M. Stępień, Dostęp do sztucznej inteligencji - równość i inne aspekty prawne dostępu do systemów sztucznej inteligencji, in: Prawo nowych technologii, dane osobowe i cyberbezpieczeństwo, Internet 
adjust the offer of insurance products to the needs and financial situation of the policyholder. ${ }^{21}$ Robo-advice (as opposed to $A l$.) is specifically designed to give personal advice, mainly with regard to investment. ${ }^{22}$ Artificial intelligence has the potential for application in many variants, offering customers a highly specialized and customer-oriented tool for selecting and using financial products. ${ }^{23}$ In most cases, the basic algorithm of robo-advice and artificial intelligence is not comprehensible. In times of crisis in the financial market, adverse market conditions (e.g. when assets depreciate) or catastrophic failures, innovation such as robo-advice or artificial intelligence may prove unreliable. Interaction between the distributor and customer may bring much more benefit. ${ }^{24}$ In a generation of advice, parametric and non-parametric statistical methods of data analysis and computing, artificial intelligence (so-called soft - computing) are used. ${ }^{25}$ The capacities of artificial intelligence (in the form of robo-analysis, robo-offer, robo-advice) will be mainly used in the insurance sector for analysis of customer needs and expectations, assessment of risk-tolerance, development of action strategy vis-a-vis the customer (preparation of the customer's financial plan, choice of asset allocation), implementation of such action strategy (opening accounts, transferring assets); as well as current monitoring and adjustment of that strategy (notification of

i media, handel elektroniczny, prawo IT, technologie, ed. X. Konarski, CH Beck, Dodatek specjalny do Monitora Prawniczego, 2019, no. 21, p. 69.

21 See more in: K. Leong, A. Sung, FinTech (Financial Technology): What is It and How to Use Technologies to Create Business Value in Fintech Way?, International Journal of Innovation, Management and Technology, 2018, vol. 9, no. 2, p. 76.

${ }^{22}$ In literature, the most frequent studies on robo-advice refer to the investment market: E. Strzelczyk, Rise of the Machines: The Legal Implications for Investor Protection with the Rise of Robo-Advisors, DePaul Business and Commercial Law Journal 2017, no. 1, p. 54 et seq.; N.G. Iannarone, Computer As Confidant: Digital Investment Advice and the Fiduciary Standard, Chicago-Kent Law Review 2018, vol. 93, p. 141 et seq.

${ }_{23}$ See more on that subject in: AI - The Potential for Automated Advisory in the Insurance Industry https:/ / www.the-digital-insurer.com/wp-content/uploads/ 2016/03/689 -AI-----The-Potential-for-Automated-Advisory-in-the-Insurance-Industry.pdf [access: 20.03.2020].

24 For pros and cons of robo-advice and its application in the insurance sector, see: T. Baker, B. Dellaert, Regulating Robo Advice Across the Financial Services Industry, Iowa Law Review 2018, vol. 103, https://scholarship.law.upenn.edu/faculty_scholarship/1740.

${ }_{25}$ See more on that subject in: M. Fras, M. Szaraniec, Nowe technologie w dystrybucji ubezpieczeń - bariery i ułatwienia w prawie polskim i unijnym. Wybrane zagadnienia prawne, Prawo Asekuracyjne, 2019, vol. 2, p. 3 et seq. 
changes, market updates and analysis of the customer's changing needs). ${ }^{26}$ Not without significance are the customer's lower costs of such innovation and the distributor's reduction in the amount of work and costs of performing the contract. ${ }^{27}$ In addition, robo-advice offers the possibility of preparing financial plans, including pension plans, assessing healthcare needs or planning real property investments. Robo-advice involves a guarantee of privacy and discretion to the customer, who may feel more comfortable without any active participation of a human advisor when discussing their financial and health matters. For many future policyholders, a matter not without significance is the fee for the provided service, which may be lower than in the case of classical advice. ${ }^{28}$

\section{Models of cooperation of robo-advisors with insurance distributors}

Robo-advisers in the financial market have all the characteristics of intelligent agents, as referred to in literature (new generation of information systems), ${ }^{29}$ since they rely on very large and disparate data sets (Big Data),

26 For more on the concerns about collecting customer data, legal questions relating to privacy and data ownership, see: P. Manes, Legal Challenges in the Realm of InsurTech, European Business Law Review 2020, vol. 31, no. 1, pp. 129-168; For more on equality and other legal aspects of access to artificial intelligence systems, see: M. Szaraniec, Artificial Intelligence and Big Data in the Operation of Insurance Companies and the Situation of Their Customers: Selected Legal Issues, in: Právo, obchod, ekonomika 9, eds. J. Suchoža, J. Husár, R. Hučková, Koszyce 2019, p. 521-531.

27 A. Cappiello, Technology and the Insurance Industry. Re-configuring the Competitive Landscape, London 2018, p. 33.

28 More on that subject in: OECD, Technology and innovation in the insurance sector, 2017, https:// www.oecd.org/pensions/Technology-and-innovation-in-the-insurance-sector.pdf [access: 13.12.2020]. It follows from the report that in the US sector of investment advice, by way of example, robo-advisors charge $1 \%$ of the managed assets as fee, and the robo-advisor Charlesa Schwaba (United Kingdom) does not charge any fees. For more on the subject of robo-advice fees, see: Accenture, The Rise of Robo-Advice. Changing the Concept of Welth Management, 2015, https://www.accenture.com/_acnmedia/PDF-2/Accenture -Wealth-Management-Rise-of-Robo-Advice.pdf [access: 20.03.2020].

29 M. Rojszczak, Prawne aspekty systemów sztucznej inteligencji - zarys problemu, in: Sztuczna inteligencja, blockchain, cyberbezpieczeństwo oraz dane osobowe, eds. K. Flaga-Gieruszyńska, J. Gołaczyński, D. Szostek, Warszawa 2019, p. 15 et seq. The cited author claims that the term "intelligent agent" is used in reference to all types of information 
which allow them to solve problems faster and with higher quality than it had been previously possible.

The business operation of insurance technology companies (InsurTech) $)^{30}$ raises a question about the legal regulation of their insurance distribution activities. Moreover, their activities trigger a question about equal competition rules in the context of the operation of traditional insurance distributors, customer safety and market security, as well as the advisability of their subjection to the regulatory provisions proper to the operation of insurance undertakings and insurance intermediaries.

The types of cooperation of InsurTech (including robo-advisors) with traditional insurance distributors have assumed, especially in foreign literature, the name of business models. ${ }^{31}$ Most InsurTech companies operate based on cooperation with either an insurance undertaking or insurance intermediary, involving the use of innovative solutions provided by external entities within the framework of an outsourcing agreement. ${ }^{32} \mathrm{Un}$ der outsourcing agreements, InsurTech companies operate as specialized service providers (subcontractors) of IT technologies and communication networks. A considerable part of innovative solutions used by insurance distributors is developed as a part of their internal structures, by their departments of development, IT or remote management of distribution channels, and certain distributors also invest in innovative enterprises.

The possibility of concluding outsourcing agreements by insurance distributors in Poland will be open only to insurance and reinsurance undertakings, since such a solution is envisaged in the Act on insurance and reinsurance activities (AIRA). ${ }^{33}$ In Art. 3(1) item 27 of that Act, the leg-

systems which, due to the ability to learn and discretion in decision-making, may independently solve problems of specific type.

30 InsurTech is a term relating to insurance technology companies providing innovative insurance services based on information technology (IT). Robo-advisors will operate as a part of InsurTech.

31 The InsurTech Book: The Insurance Technology Handbook for Investors, Entrepreneurs and FinTech Visionaries, ed. S.L.B VanderLinden et al., Chichester 2018, p. 186-121.

32 PWC Global InsurTech Report, 2017, https://www.pwc.ch/en/publications/2017/ pwc_insurances_new_normal_report_2017_en.pdf [access: 13.12.2020]. The PwC report shows that more than a half of all insurers regard innovation as a priority strategic area, which is why increasingly more often they establish cooperation with InsurTech companies.

33 See: Art. 73-76 of the Act of 15 September 2015 on insurance and reinsurance activities, Journal of Laws of 2019 item 381. The areas most frequently covered by outsourcing in insurance undertakings are: claims adjustment, provision of regular or permanent support 
islator adopted a broad definition of an outsourcing agreement, ${ }^{34}$ and then the subjective scope of such contract was narrowed down under Art. 73 AIRA, only to certain insurance activities and to so-called functions included in the management system, whereby in specifically listed situations outsourcing service providers are exempt from insurance secrecy. ${ }^{35}$ The provision of Art. 73 AIRA contains an exhaustive catalogue of activities and functions that may be entrusted by an insurance undertaking to service providers within an outsourcing agreement framework. ${ }^{36}$ Consequently, the possibility must be excluded that an insurance undertaking might entrust to a service provider, by way of outsourcing agreement, the performance of any activities and functions other than the ones directly and expressly listed in Art. 73 AIRA. ${ }^{37}$ Although any entrepreneur may be a party to an outsourcing agreement, such construction of the outsourcing contract (i.e. its narrowed subjective scope) under the AIRA does not allow to take full advantage of the provisions of IT technologies and communication networks by InsurTech companies in the insurance industry. ${ }^{38}$ It should also be stressed that AIRA not only does not prohibit the possibility of further subcontracting by the service provider of the undertaking's

in compliance, internal audit, accounting, risk management and actuarial services as well as data storage.

34 "Outsourcing means a contract between an insurance or reinsurance undertaking and service provider under which the service provider performs a process, service of activity which would be otherwise performed by the insurance or reinsurance undertaking, or a contract under which a service provider entrusts performance of such process, service or activity to other entities, through which the service provider renders a given process service or activity".

35 So: Art. 35(2) item 26 AIRA.

36 Otherwise: P. Machulak, J. Ziemba, Outsourcing w działalności ubezpieczeniowej i reasekuracyjnej - zagadnienia prawne, Wiadomości Ubezpieczeniowe 2018, no. 4, p. 3 et seq.

37 P. Wajda, in: Ustawa o działalności ubezpieczeniowej i reasekuracyjnej. Komentarz, eds. M. Szczepańska, P. Wajda, Warszawa 2017, p. 376. The same in: M. Kozłowska, in: Ustawa o działalności ubezpieczeniowej i reasekuracyjnej. Komentarz, ed. P. Czublun, Warszawa 2016, p. 197.

38 Outsourcing of information technology activities should be understood in the wide sense of that term, as, among others, installation or servicing of software/financial institution systems, and performance of activities with the use of such systems, including activities using cloud computing, by external entities with or without access to (different types of) information stored in the systems. So: J. Byrski, Outsourcing w działalności dostawców ustug ptatniczych, Warszawa 2018, p. 139. 
activities or functions to another entity (sub-outsourcing) ${ }^{39}$ but allows for such possibility directly under the definition of outsourcing. Art. 76 AIRA guarantees that insurance and reinsurance undertakings will retain full responsibility for the performance of all their liabilities under the Act in the event of delegating, by way of outsourcing, operational functions or insurance or reinsurance activities. On top of that, the legislator prohibited the excluding or limiting of the insurance undertaking's liability for damages caused respectively to policyholders, insured parties or beneficiaries of insurance contracts. ${ }^{40}$ It must be emphasized that the problems of outsourcing agreements being concluded by other distributors (e.g. by brokers) are not regulated at all in the Insurance Distribution Act. ${ }^{41}$ Such a situation poses an important barrier on the economic insurance market to the development of cooperation between InsurTech companies and traditional insurance distributors and calls for the introduction of appropriate legal provisions by the legislator in this regard. De lege ferenda, it should be postulated that the legislator provides outsourcing agreements for the activities in the area of information technology (IT) in respect of all distributors (and the related liability of the parties). ${ }^{42}$

39 Such situation is permissible, e.g. in banking activities. See more on that subject in: Ibidem, p. 90 et seq.

40 In literature, based on the example of the banking market, it is argued that such an absolute prohibition does not meet the test of proportionality of regulation. The author is of the opinion that the legislator should introduce a provision obligating payment service providers to implement an adequate and effective solution securing the coverage of possible costs relating to the payment of compensation in case of customer claims for the redress of damage caused by non-performance or improper performance of a contract, e.g. by civil liability insurance of such outsourcing partner. So: Ibidem, p. 466-467.

${ }^{41}$ One should point in this regard to Art. 31 IDA, under which: "An insurance broker may entrust performance of activities requiring specialist knowledge to other entities, excluding the right to make and receive declarations of intent on customers' behalf". Also, the construction of that provision does not allow to fully take advantage in the insurance industry of the provision of information technologies and communication networks by InsurTech companies.

42 The objective scope of regulation of the outsourcing agreement is much broader on the banking market where the legislator allows banking institutions, on the basis of such agreements, to delegate much more banking activities and factual operations relating to banking to an outsourcing partner (See: Art. 6a-6e of the Act of 29 August 1997 - Banking Law, i.e.: Journal of Laws of 2018 item 2187, or Art. 9a-9d of the Act of 5 November 2009 on cooperative savings and credit unions, i.e.: Journal of Laws of 2018 item 2386), but also analogically as in the Act on insurance and reinsurance activities - imposes a prohibition 
If insurance technology companies (InsurTech) wished to operate independently as insurance undertakings or as insurance intermediaries, they would have to meet the statutory requirements provided for such financial institutions. This is the case because many statutory prerequisites must be met before a permit for the exercise of brokerage activities is issued.

The investigations on this subject allowed us to determine that, under the Insurance Distribution Act, outsourcing is not legally regulated, which leads to a situation in which traditional brokers have no legislative grounds to conclude such agreements. The lack of contraindications might be traced to the generally applicable civil law principle of contractual freedom or the generally accepted formula: "what is not prohibited is permitted." However, these are not the intentions and expectations of the European Union legislator, who sees the need to regulate outsourcing in insurance law and considers it necessary to submit such outsourcing to supervision by EU and national supervisory authorities. EIOPA guidelines may serve as an example regarding the supervision of outsourcing to cloud service providers. ${ }^{43} \mathrm{EBA}$ issued similar guidelines regarding the supervision of outsourcing in the banking sector. ${ }^{44}$ As a result, the EU legislator's intention is not only to regulate but also to ensure strict supervision of outsourcing in the financial market. The absence of such provisions in the Insurance Distribution Act is a serious shortcoming and barrier to the establishment of cooperation between brokers and robo-advisors. ${ }^{45}$

of limiting or excluding such partner's liability vis-a-vis banks. However, a new solution is the introduction in the Act on payment services of an exemption from application of the provisions on payment outsourcing to services rendered by technical service providers, insofar as they do not come into possession of monetary funds subject to the payment transaction (So: Art. 6 item 10 of the Act of 19 August 2011 on payment services, Journal of Laws of 2017 item 2003. For more on that, see: J. Byrski, Outsourcing w działalności..., p. 307 et seq.). As a result, the legislator should strive that the legal provisions on the outsourcing agreement in the financial market be uniform and consistent.

43 EIOPA, Consilts on guidelines on outsourcing to cloud service providers, https://eiopa.europa.eu/Pages/News/EIOPA-consults-on-guidelines-on-outsourcing-to-cloud-service-providers.aspx of 2.07.2019 [access: 13.12.2020].

44 EBA, Wytyczne w sprawie outsourcingu, sprawozdanie końcowe, 25 February 2019, https:/ / eba.europa.eu/documents/10180/2761380/EBA+revised+Guidelines+on+outsourcing_PL.pdf/7551b1c5-534d-44aa-b524-61eb8929154d [access: 13.12.2020].

45 More on regulatory dilemmas in: U. Pagallo, M. Corrales, M. Fenwick, N. Forgó, The Rise of Robotics \& AI: Technological Advances $\mathcal{E}$ Normative Dilemmas, in: Robotics, AI and the Future of Law, eds. M. Corrales, M. Fenwick, N. Forgó, Singapore 2018, p. 1-15 or 


\section{Robo-advice and civil law liability}

An important question relating to the development and regulation of artificial intelligence is undoubtedly the problem of liability for violations made by AI-controlled solutions, which inseparably relates to Al's legal subjectivity problem. ${ }^{46}$ Authors of the Policy for the Development of Artificial Intelligence in Poland for the years 2019-2027, prepared by the Ministry of Digitalization, ${ }^{47}$ clearly emphasize the significance of the concept of human- and human environment-oriented artificial intelligence $(\mathrm{Hu}-$ man-Centric Approach), whose aim is to strive that human values be of key importance to the methods of developing, implementing, using and monitoring artificial intelligence systems. Poland believes and supports countries that refuse to grant artificial intelligence systems with a citizen or legal status. According to the Policy for the Development of Artificial Intelligence in Poland, such conception would be contrary to the abovementioned concept of human-oriented artificial intelligence. Poland supports the conception of human supremacy over Al systems. As has been highlighted in Annex 3 to the Policy for the Development of Artificial Intelligence in Poland, one should oppose the aspirations to grant legal personality to $\mathrm{Al}^{48}$ The European Parliament, in the Resolution of 16.02.2017, clearly states that the development of technologies relating to robotics should be, in large measure, based on complementation rather than replacement of human capacities. It is argued that in the development of robots and artificial intelligence, it is of key importance to make sure that a human agent may always control intelligent machines. Important

V. Chatzara, FinTech, InsurTech, and the Regulatorss, in: InsurTech: A Legal and Regulatory View, eds. P. Marano, K. Noussia, Cham 2020, p. 3-26; P. Maume, Regulating Robo-Advisory, Texas International Law Journal 2019, vol. 55, no. 1, p. 49-88.

46 The limited scope of this study does not permit to take a broader look at the problem. More on that subject may be found, e.g., in.: M. Uliasz, Sztuczna inteligencja jako sztuczna osoba prawna, in: Sztuczna inteligencja, blockchain..., p. 26 et seq. or M. Jankowska-Augustyn, Podmiotowość prawna sztucznej inteligencji?, in: O czym mówia prawnicy, mówiąc o podmiotowości, ed. A. Bielska-Brodziak, Katowice 2015, p. 177, or R. van den Hoven van Genderen, Do We Need New Legal Personhood in the Age of Robots and AI?, in: Robotics, AI and the Future of Law..., p. 15-57.

47 Polityka rozwoju sztucznej inteligencji w Polsce na lata 2019-2027, https:/ / www.gov.pl/ attachment/0aa51cd5-b934-4bcb-8660-bfecb20ea2a9 [access: 13.12.2020].

48 See more on that in: E. Kurowska-Tober, Ł. Czynienik, M. Koniarska, Aspekty prawne sztucznej inteligencji - zarys problematyki, in: Prawo nowych technologii..., p. 86. 
considerations regarding the liability for damages caused by Al have been included in the abovementioned Policy for the Development of Artificial Intelligence in Poland for the years 2019-2027. According to the above document, Poland is in favour of human supremacy over Al systems and, in consequence, the liability of humans or legal persons established and managed by humans.

Returning to the leading theme of this study, it seems that liability and accountability for activities are the most serious problem connected with the operation of robo-advisors (software advisors) in insurance distribution, or, to be more precise, in brokerage activities. Such solutions are most frequently results of cooperation of multiple parties, just as in insurance outsourcing we have to do with service providers (subcontractors) specific to information technologies or communication networks and traditional distributors, and the lack of dedicated provisions specifying the cooperation in itself and, consequently, the terms of establishing liability (including the limits to such liability) is increasingly often indicated as one of the major barriers to the development of $\mathrm{Al}$ in the insurance market. In each system taking advantage of machine learning techniques, the class of responsible entities should include the manufacturer, the operator (entity responsible for its operation) and coach (entity influencing adequate preparation of the system for work). The situation is further complicated by the fact that, depending on the level of the system's involvement in making its own decisions and its period of operation, the burden of liability will be shifting from the manufacturer to the operator, and then from the operator to the coach. It is a complicated task to weigh the liability among those parties, and most often, it is impossible from the point of view of the injured party. Also, from the perspective of professional manufacturers and providers of intelligent agents (robo-advisors), the situation in which the scope of their liability is unknown and may vary over time, which is difficult to predict by such professionals, seems unacceptable. ${ }^{49}$

The above solutions allow the adoption of a solution relating to the concept of risk-based (strict) liability for damages caused by artificial intelligence systems. Such an approach to the problem allows us to avoid the necessary demonstration of an adequate causal link. This would imply liability in case of causing unlawful damage to a third party regardless of the fault of the party using the AI. There are attempts in literature to

${ }^{49}$ M. Rojszczak, Prawne aspekty..., p. 17. 
solve the problem of cooperation between multiple entities by the concept of the $\mathrm{Al}^{\prime} \mathrm{s}$ actual administrator. ${ }^{50}$ The author of that conception proposes the following division of liability: in the event of $\mathrm{Al}$ actions causing third party damage - the responsible party would be the $\mathrm{Al}^{\prime}$ s manufacturer (creator), however, only as far as the irregular activities of the AI were embedded in the original algorithm. Otherwise, in case of the $\mathrm{Al}^{\prime}$ 's actions leading to third party damages, the liability would be with the Al's administrator, that is, the owner, lessee, license holder, etc. Finally, when we have to do with more than one such AI's administrator, the logical solution would be to distribute the liability jointly and severally among those entities. ${ }^{51} \mathrm{In}$ such a case, traditional exclusions of liability would apply, such as force majeure or the injured party's exclusive fault.

Another approach is to invoke the construction of liability for a hazardous product. However, this conception of liability is not fully adequate to the circumstances of artificial intelligence operation either. This is a regime of risk-based (strict) liability, and, in principle, it does not require to demonstrate the manufacturer's fault. This time, doubts are raised by the definition of "product" under Polish legislation since, under Art. 4491 $\S 2$ of the Civil Code, a product is a movable thing, animal or electricity. As a result, a problem arises if an information system may be regarded as a product, especially when it is not recorded on a data carrier but exists in a distributed information network, such as the Internet. In certain situations, an intelligent agent will be a part of a movable thing (e.g. in autonomous vehicles). However, many such systems operate only as Internet services, such as intelligent bots or Big Data analytics systems. In such a situation, intelligent agents may be treated only as intangible goods, which results in their exclusion from the regime of liability for a hazardous product. In effect, the applicable civil law norms make it difficult to determine both the terms of liability for damages caused by intelligent agents' decisions and the group of obliged parties. ${ }^{52}$

50 A. Chłopecki, Sztuczna inteligencja - szkice prawnicze i futorologiczne, Warszawa 2018, [database LEX] 2020, chapter 7: Sztuczna inteligencja a czyny niedozwolone i prawo karne.

51 So: E. Kurowska-Tober, Ł. Czynienik, M. Koniarska, Aspekty prawne..., p. 87 and 88. Otherwise: M. Rojszczak, Prawne aspekty..., p. 17. The author claims that introduction of the legal presumption under which administrators of the same $\mathrm{Al}$ are to be treated as joint actors does not allow to remove numerous interpretative doubts.

52 So after: M. Rojszczak, Prawne aspekty..., p. 17. The author draws attention to the provision of Art. $449^{3} \S 2$ of the Civil Code under which the manufacturer is not liable 
The directions of work on the law of artificial intelligence are set by the abovementioned European Parliament resolution of 16 February 2017 with recommendations to the Commission on Civil Law Rules on Robotics. In that resolution, an opinion was presented that civil liability for damages caused by a robot is a matter of key importance that should be resolved at the European Union level. It was suggested that legislative conclusions might envisage fault-independent liability, which would consider the level of the robot's autonomy. It was pointed out that liability must attach to humans and not to robots, at least at the present stage. The Parliament considered the possibility to apply methods of protecting against damage other than compensatory liability, in particular by introducing a system of compulsory insurance supplemented by a guarantee fund. The Resolution also calls on the Commission to consider the consequences of granting a specific legal status for robots in the long run, so that at least the most sophisticated autonomous robots could be established as having the status of electronic persons responsible for making good any damage they may cause, and possibly applying electronic personality to cases where robots make autonomous decisions or otherwise interact with third parties independently. ${ }^{53}$

The above considerations have shown that the applicable Polish civil law norms on civil liability are not keeping pace with the development of new technologies and, what is more, may lead to a decline of interest in that area or slow down investment supporting economic development. As

for the damage caused if the product's hazardous properties could not have been predicted, considering the state of science and technology, as on the date of placing the product on the market. The author notes that in the case of intelligent agents it may be problematic to even point to the date of their manufacture or placement on the market, which means that attaching the manufacturer's liability to the decision made by such manufacturer at the time of placing the product on the market and exclusion based on the data available at that time does not allow to duly secure the interests of the existing users. In that author's opinion, Al systems should meet the criterion of safety not only at the time of being placed on the market but also throughout the entire operating life.

53 See more in: M. Fras, M. Szaraniec, Digital consultancy, artificial intelligence and smart contracts in insurance distribution. Selected legal problems, in: Public Law and the Challenges of New Technologies and Digital Markets, eds. E. Bani, E. Rutkowska-Tomaszewska, B. Pachuca-Smulska, 2020 (in press). On that subject, see also: E. Karner, Liability for Robotics: Current Rules, Challenges, and the Need for Innovative Concepts, in: Liability for Artificial Intelligence and the Internet of Things, eds. S. Lohsse, R. Schulze, D. Staudenmayer, Baden-Baden 2019, p. 117-124. 
a result, it should be postulated that the legislator readjusts the provisions on liability for a hazardous product since the currently applicable regime of liability for a hazardous product is insufficient. It is impossible not to mention that the Civil Code's respective provisions are an implementation of the over 30-year old EU Directive 85/373/EWG ${ }^{54}$ concerning liability for defective products. Simultaneously, the next thing to do should be to strive toward the development of new terms of civil law liability with regard to damages caused by artificial intelligence.

\section{Conclusion}

The considerations made in this study allowed us to determine who, under the Polish distribution model, may provide advice (in understanding the provisions of the IDD). Attention was drawn to the question of missing implementation in the Polish Act of the obligation under Art. 18(1) (ii) IDD.

On the other hand, the analysis of insurance outsourcing allowed to establish that there are no legal solutions in this regard in the Polish Insurance Distribution Act, which makes an important legal gap, especially that such type of cooperation model is to be subjected (on the initiative of the EU legislator) to the review by national supervisory authorities. Simultaneously, it must be concluded that the legal regime of insurance outsourcing is lagging far behind the legal regime of outsourcing in the banking market. As a result, it will soon be necessary to level out the differences in the legal regimes of those two segments of the financial market (baking and insurance) to preserve legal coherence and customer safety in the financial market as a whole.

Also, the applicable civil law norms in Polish and EU legislation on civil liability for damages caused by artificial intelligence are not keeping pace with the development of new technologies. Taking into consideration the problems discussed in this study, mainly at the level of Polish legislation, it should be postulated that those matters be regulated at the level of

54 Council Directive 85/374/EEC of 25 July 1985 on the approximation of the laws, regulations and administrative provisions of the Member States concerning liability for defective products (OJ L 210, 1985, p. 29). 
EU law. Considering the specificity of the Internet, whose inherent aspect is cross-border, supranational transfer of data, it seems dubious that individual Member States might introduce effective legal norms governing the use of software agents. Therefore, it must be regretted that the EU legislator has not worked out any supranational and legally binding agreement on the $\mathrm{Al}$ regime.

\section{Bibliography}

Auleytner A., Stępień M., Dostęp do sztucznej inteligencji - równość $i$ inne aspekty prawne dostęp do systemów sztucznej inteligencji, in: Prawo nowych technologii, dane osobowe i cyberbezpieczeństwo, Internet $i$ media, handel elektroniczny, prawo IT, technologie, ed. X. Konarski, Dodatek specjalny do Monitora Prawniczego 2019, no. 21.

Baker T., Dellaert B., Regulating Robo Advice Across the Financial Services Industry, Iowa Law Review 2018, vol. 103, https://scholarship.law.upenn.edu/faculty_scholarship/1740 [access: 13.12.2020].

Byrski J., Outsourcing w działalności dostawców ustug płatniczych, Warszawa 2018.

Cappiello A., Technology and the Insurance Industry. Re-configuring the Competitive Landscape, London 2018.

Chatzara V., FinTech, InsurTech, and the Regulatorss, in: InsurTech: A Legal and Regulatory View, eds. P. Marano, K. Noussia, Cham 2020.

Chłopecki A., Sztuczna inteligencja - szkice prawnicze i futurologiczne, Warszawa 2018.

Fras M., Umowa ubezpieczenia grupowego. Aspekty prawne, Warszawa 2015.

Fras M., Szaraniec M., Nowe technologie w dystrybucji ubezpieczeń - bariery i ułatwienia w prawie polskim i unijnym. Wybrane zagadnienia prawne, Prawo Asekuracyjne 2019, vol. 2.

Fras M., Szaraniec M., Digital consultancy, artificial intelligence and smart contracts in insurance distribution. Selected legal problems, in: Public Law and the Challenges of New Technologies and Digital Markets, eds. E. Bani, E. Rutkowska-Tomaszewska, B. Pachuca-Smulska, 2020 (in press).

van den Hoven van Genderen R., Do We Need New Legal Personhood in the Age of Robots and AI?, in: Robotics, AI and the Future of Law, ed. M. Corrales, M. Fenwick, N. Forgó, Singapore 2018.

Leong K., Sung A., FinTech (Financial Technology): What is It and How to Use Technologies to Create Business Value in Fintech Way?, International Journal of Innovation, Management and Technology 2018, vol. 9, no. 2. 
Lewaszkiewicz-Petrykowska B., Uwagi o zawodowym obowiazku udzielenia informacji, in: Z zagadnień współczesnego prawa cywilnego. Księga pamiątkowa ku czci Profesora Tomasza Dybowskiego, Warszawa 1994.

Iannarone N.G., Computer As Confidant: Digital Investment Advice and the Fiduciary Standard, Chicago-Kent Law Review 2018, vol. 93.

Jankowska-Augustyn M., Podmiotowość prawna sztucznej inteligencji?, in: O czym mówią prawnicy, mówiąc o podmiotowości, ed. A. Bielska-Brodziak, Katowice 2015.

Karner E., Liability for Robotics: Current Rules, Challenges, and the Need for Innovative Concepts, in: Liability for Artificial Intelligence and the Internet of Things, eds. S. Lohsse, R. Schulze, D. Staudenmayer, Baden-Baden 2019.

Kozłowska M., in: Ustawa o działalności ubezpieczeniowej i reasekuracyjnej. Komentarz, ed. P. Czublun, Warszawa 2016.

Kurowska-Tober E., Czynienik Ł., Koniarska M., Aspekty prawne sztucznej inteligencji - zarys problematyki, in: Prawo nowych technologii, dane osobowe i cyberbezpieczeństwo, Internet i media, handel elektroniczny, prawo IT, technologie, ed. X. Konarski, CH Beck, Dodatek specjalny do Monitora Prawniczego 2019, no. 21.

Machulak P., Ziemba J., Outsourcing w działalności ubezpieczeniowej i reasekuracyjnej - zagadnienia prawne, Wiadomości Ubezpieczeniowe 2018, no. 4.

Manes P., Legal Challenges in the Realm of InsurTech, European Business Law Review 2020, vol. 31, no. 1.

Maśniak D., Komentarz do art. 4 u.d.u., in: Dystrybucja ubezpieczeń. Komentarz, M. Fras, B. Kucharski, K. Malinowska, D. Maśniak, M. Szaraniec, Warszawa 2020.

Maśniak D., Malinowska K., Czynności dystrybucyjne w nowym reżimie zawierania umów ubezpieczenia - wybrane aspekty implementacji dyrektywy nr 2016/97 w sprawie dystrybucji ubezpieczeń, Prawo Asekuracyjne 2017, vol. 2.

Maume, P. Regulating Robo-Advisory, Texas International Law Journal 2019, vol. 55 , no. 1 .

Pagallo U., Corrales M., Fenwick M., Forgó N., The Rise of Robotics E AI: Technological Advances \& Normative Dilemmas, in: Robotics, AI and the Future of Law, eds. M. Corrales, M. Fenwick, N. Forgó, Singapore 2018.

Rojszczak M., Prawne aspekty systemów sztucznej inteligencji - zarys problemu, in: Sztuczna inteligencja, blockchain, cyberbezpieczeństwo oraz dane osobowe, eds. K. Flaga-Gieruszyńska, J. Gołaczyński, D. Szostek, Warszawa 2019.

Strzelczyk E., Rise of the Machines: The Legal Implications for Investor Protection with the Rise of Robo-Advisors, DePaul Business and Commercial Law Journal 2017, no. 1 .

Szaraniec M., Artificial Intelligence and Big Data in the Operation of Insurance Companies and the Situation of Their Customers: Selected Legal Issues, in: Právo, obchod, ekonomika 9, eds. J. Suchoža, J. Husár, R. Hučková, Koszyce 2019. 
Tereszkiewicz P., Obowiazki informacyjne w umowach o ustugi finansowe, Warszawa 2015.

The InsurTech Book: The Insurance Technology Handbook for Investors, Entrepreneurs and FinTech Visionaries, eds. S. L.B VanderLinden et. al., Chichester 2018.

Uliasz M., Sztuczna inteligencja jako sztuczna osoba prawna, in: Sztuczna inteligencja, blockchain, cyberbezpieczeństwo oraz dane osobowe, ed. K. Flaga-Gieruszyńska, J. Gołaczyński, D. Szostek, Warszawa 2019.

Wajda P., in: Ustawa o działalności ubezpieczeniowej i reasekuracyjnej. Komentarz, eds. M. Szczepańska, P. Wajda, Warszawa 2017.

\section{Sum mary}

This article relates to the problems of introducing new technologies in the activities of insurance distributors, especially brokers, and points to essential legal aspects of non-adjustment or absence of legal solutions in this respect. The author focused her investigations on the essence, application of robo-advice in economic insurance, as well as its admissibility in the Polish insurance distribution model. The article points to the types of cooperation of robo-advisors with the traditional insurance distributor and imperfections of the outsourcing agreement's legal regime. The applicable Polish civil law norms on civil liability for damages caused by artificial intelligence are also not keeping pace with the development of new technologies and require reform, in the first place, on the level of UE law.

Key words: insurance distributor, robo-advisor, artificial intelligence, civil liability, outsourcing agreement

\section{ROBO-ADVICE W DYSTRYBUCJI UBEZPIECZEŃ W PRAWIE POLSKIM. ZARYS PROBLEMU}

\section{Streszczenie}

Artykuł jest związany z problematyką wprowadzania nowych technologii w działalności dystrybutorów ubezpieczeń, w szczególności brokerów, i wskazuje na istotne aspekty prawne niedostosowania lub braku rozwiązań prawnych w tym zakresie. Autorka skoncentrowała swoje rozważania na istocie, zastosowaniu robo-porady w ubezpieczeniach gospodarczych, a także jej dopuszczalności w polskim modelu dystrybucji ubezpieczeń. W artykule zostały wskazane rodzaje współpracy robo-doradców z tradycyjnym dystrybutorem ubezpieczeń oraz niedoskonałości regulacji prawnej umowy outsourcingu. Obowiązujące 
normy prawa cywilnego w prawie polskim w zakresie odpowiedzialności cywilnej w odniesieniu do szkód wyrządzonych przez sztuczną inteligencję także nie nadążają za rozwojem nowych technologii i wymagają zmian przede wszystkim na poziomie prawa UE.

Słowa kluczowe: dystrybutor ubezpieczeń, robo-doradca, sztuczna inteligencja, odpowiedzialność cywilna, umowa outsourcingu

\section{ROBO-ADVICE ПО РАСПРОСТРАНЕНИЮ СТРАХОВЫХ УСЛУГ В ПОЛЬСКОМ ПРАВЕ. КРАТКОЕ ИЗЛОЖЕНИЕ ПРОБЛЕМЫ}

\section{Резюме}

Статья касается вопроса внедрения новых технологий в деятельность страховых дистрибьюторов, в частности брокеров, и указывает на существенные правовые аспекты неприспособленности или отсутствия правовых решений в этой сфере. Автор сосредоточила свои размышления на сути, применении робо-совета в экономическом страховании, а также его допустимости в польской модели распространения страховых услуг. В статье указаны виды сотрудничества роботов-консультантов (робо-эдвайзеров) с традиционным страховым дистрибьютором и недостатки правового регулирования договора аутсорсинга. Действующие нормы гражданского законодательства в польском праве в области гражданской ответственности в отношении ущерба, причиненного искусственным интеллектом, также не успевают за развитием новых технологий и требуют изменений, прежде всего, на уровне законодательства ЕС.

Ключевые слова: страховой дистрибьютор, робот-консультант, искусственный интеллект, ответственность перед третьими лицами, договор аутсорсинга 
